\title{
Molecular identification and antimicrobial activities of some wild Egyptian mushrooms: Bjerkandera adusta as a promising source of bioactive antimicrobial phenolic compounds
}

\author{
Elham R. S. Soliman * (i) and Heba El-Sayed
}

\begin{abstract}
Background: The discovery of potential, new cost-effective drug resources in the form of bioactive compounds from mushrooms is one way to control the resistant pathogens. In the present research, the fruiting bodies of five wild mushrooms were collected from Egypt and identified using internal transcribed spacer region (ITS) of the rRNA encoding gene and their phylogenetic relationships, antimicrobial activities, and biochemical and phenolic compounds were evaluated.

Results: The sequences revealed identity to Bjerkandera adusta, Cyclocybe cylindracea, Agrocybe aegerita, Chlorophyllum molybdites, and Lentinus squarrosulus in which Cyclocybe cylindracea and Agrocybe aegerita were closely related, while Chlorophyllum molybdites was far distant. Cyclocybe cylindracea and Agrocybe aegerita showed 100\% similarity based on the sequenced ITS-rDNA fragment and dissimilar antimicrobial activities and chemical composition were detected. Bjerkandera adusta and Cyclocybe cylindracea showed strong antimicrobial activity against Escherichia coli, Pseudomonas aeruginosa, Staphylococcus aureus, Micrococcus luteus, Streptococcus pneumoniae, and Candida albicans. This activity could be attributed to the detected phenolic and related compounds' contents.
\end{abstract}

Conclusion: Our finding provides a quick and robust implement for mushroom identification that would facilitate mushroom domestication and characterization for human benefit.

Keywords: Phylogenetic, HPLC, Fruiting fungi, rRNA-ITS

\section{Background}

Mushrooms belong to a special group of macroscopic fungi with distinctive fruiting bodies of Basidiomycota and some belong to Ascomycota [1]. In areas with high humidity, wild mushrooms grow naturally on tree trunks or rotting woody debris. They are used as nutritious foods and therapeutic sources worldwide

\footnotetext{
* Correspondence: Elham_soliman@science.helwan.edu.eg

Botany and Microbiology Department, Faculty of Science, Helwan University, Helwan, Egypt
}

$[2,3]$, as well as excellent recyclers and decomposers [4], and thus play a significant role throughout the environment. They are typically abundant worldwide during the wet season and have been discovered grown on different substrates $[5,6]$.

Mushrooms have a high content of proteins, carbohydrates, crude fibers, minerals, vitamins, and secondary metabolites, as well as a source of bioactive substances that promote good health, e.g., antioxidants, antimicrobials, anticancer, cholesterol-lowering, and immunestimulating effects have been reported for certain
Springer Open

(c) The Author(s). 2021 Open Access This article is licensed under a Creative Commons Attribution 4.0 International License, which permits use, sharing, adaptation, distribution and reproduction in any medium or format, as long as you give appropriate credit to the original author(s) and the source, provide a link to the Creative Commons licence, and indicate if changes were made. The images or other third party material in this article are included in the article's Creative Commons licence, unless indicated otherwise in a credit line to the material. If material is not included in the article's Creative Commons licence and your intended use is not permitted by statutory regulation or exceeds the permitted use, you will need to obtain permission directly from the copyright holder. To view a copy of this licence, visit http://creativecommons.org/licenses/by/4.0/. 
mushroom species [7-9]. Accurate identification knowledge of edible mushrooms is essential for effective exploration in human benefits. About 140,000 different species of mushrooms exist on the planet; only about $10 \%$ is well characterized. As macroscopic fungi, mushrooms are identified depending on their morphological characters. Nowadays, molecular markers are prevailed in the identification of different organisms because of their robustness and efficiency. Identification based on direct sequencing of the internal transcribed spacers region of the rRNA encoding gene is a precise tool for identification and constructing phylogenetic relationships among different organisms or species [10]. Nineteen mushroom samples of Termitomyces aurantiacus, Tricholoma matsutake, Tricholoma robustum, P. ostreatus, Schizophyllum commune, and Pleurotus pulmonarius collected from Southwest Nigeria were successfully identified using the rDNA-ITS region and the obtained sequences were used to construct their phylogenetic relatedness with reference strains in the NCBI gene-bank [11]. Molecular identification using the rDNA-ITS region as a basis for species identification was generated for 33 representative mushroom samples collected from powdered mycelium samples, grocery store mushrooms, and capsules from commercial dietary supplements. Generally, the ITS sequences were efficaciously applied to verify and certify dietary supplements containing mushrooms [12].

Extracts from several mushroom species have been reported to have antimicrobial activity derived from their phenolic contents [13-15]. Phenolic acids prevailed in mushrooms, including benzoic and cinnamic acid derivatives. In numerous mushroom species, phydroxybenzoic, protocatechuic, gallic, vanillic, and syringic acids have been found. Cinnamic acid and its derivatives, such as $\mathrm{P}$-coumaric acid, O-coumaric acid, caffeic acid, ferulic acid, and chlorogenic acid, were also reported. Certain flavonoids such as quercetin, rutin, and chrysin have been identified [16].

The present study aimed to employ molecular characterization for the identification of morphologically different mushrooms collected from Egypt. The discovery of new cost-effective drug resources in the form of bioactive compounds from mushrooms as a promising source of them is one way to control drug-resistant pathogens. In this regard, the bioactivity of mushroom extracts was evaluated in an attempt to explore new natural sources for controlling widespread microbes affecting human health.

\section{Methods}

\section{Mushroom samples}

Five morphologically different wild mushrooms labeled Mush 1 to 5 were collected from their natural habitat in
Al-Beheira Governorate and Cairo, Egypt, between January and February 2017. The mushroom samples were characterized morphologically following the methodology suggested by Largent and Stuntz [17]. The samples verified up to genus level [18] as follows: Mush 1, Bjerkandera sp.; Mush 2 and 3, Cyclocybe sp.; Mush 4, Chlorophyllum sp.; and Mush 5, Lentinus (Fig. 1). The samples were dried at room temperature to a constant weight, then preserved in a dry place until use. The macroscopic features of the collected mushroom were recorded. The specimens collected were deposited in Mycology Laboratory, Faculty of Science, Helwan University, Egypt.

\section{DNA isolation and molecular identification}

Total genomic DNA was isolated from fruit bodies according to [19]. The total isolated DNA were column purified using DNA Purification MiniSpin Kit (VIOGENE cat\# PF1001) according to the manufacturer's protocol. The purified DNA was used as a template for PCR reaction using Mytaq Red DNA polymerase master mix (BIOLINE cat \# BIO-21108) according to manufacture instructions. Briefly, the reaction was containing $1 \times$ PCR red master mix buffer, $2.0 \mu \mathrm{l}$ of $10 \mathrm{pm} / \mu \mathrm{l}$ of each primer; ITS1 (5' TCCGTAGGTGAACCTGCGG 3') and ITS4 (5' TCCTCCGCTTATTGATATGC 3'), $1.0 \mu \mathrm{l}$ of DNA template $(\sim 30 \mathrm{ng}), 0.25 \mu \mathrm{l}$ of $\mathrm{MyTaq}^{\mathrm{m}}$ DNA polymerase $(5 \mathrm{U} / \mu \mathrm{l})$, then the total volume was adjusted to $50 \mu \mathrm{l}$ using sterile water. The amplification reactions were performed in Thermal Cycler (Biometra, Germany) as follow: 1st cycle of $3 \mathrm{~min}$ at $95{ }^{\circ} \mathrm{C}$ for initial denaturation, followed by 35 cycles of $20 \mathrm{~s}$ at $95{ }^{\circ} \mathrm{C}$ (denaturation), $20 \mathrm{~s}$ at $55{ }^{\circ} \mathrm{C}$ (annealing), $30 \mathrm{~s}$ at $72{ }^{\circ} \mathrm{C}$ (extension), and then a final extension was carried out for $10 \mathrm{~min}$ at $72{ }^{\circ} \mathrm{C}$; the reaction was held at $4{ }^{\circ} \mathrm{C}$. The PCR products were separated on $1 \%$ agarose gel, the amplified fragments were purified using a PCR-M cleanup system (VIOGENE cat\# PF1001) according to the manufacturer's protocol, followed by sequencing with ITS1 primer at GATC Company using ABI 3730xl DNA-sequencer.

\section{Sequencing data analysis}

The obtained nucleotide sequences were aligned to the total nucleotide collection of NCBI using Basic Local Alignment Search Tool for nucleotide blast (https:// blast.ncbi.nlm.nih.gov/Blast.cgi). The phylogenetic tree is constructed using the UPGMA tree build method with 100 bootstrapping in Geneious 8.1.9 software [20].

\section{Preparation of ethanol crude extracts}

Dried fruiting bodies were grounded in a grinder into a fine powder before extraction. Five grams of the powdered samples were extracted with $95 \%$ ethanol $(50 \mathrm{~mL})$ 


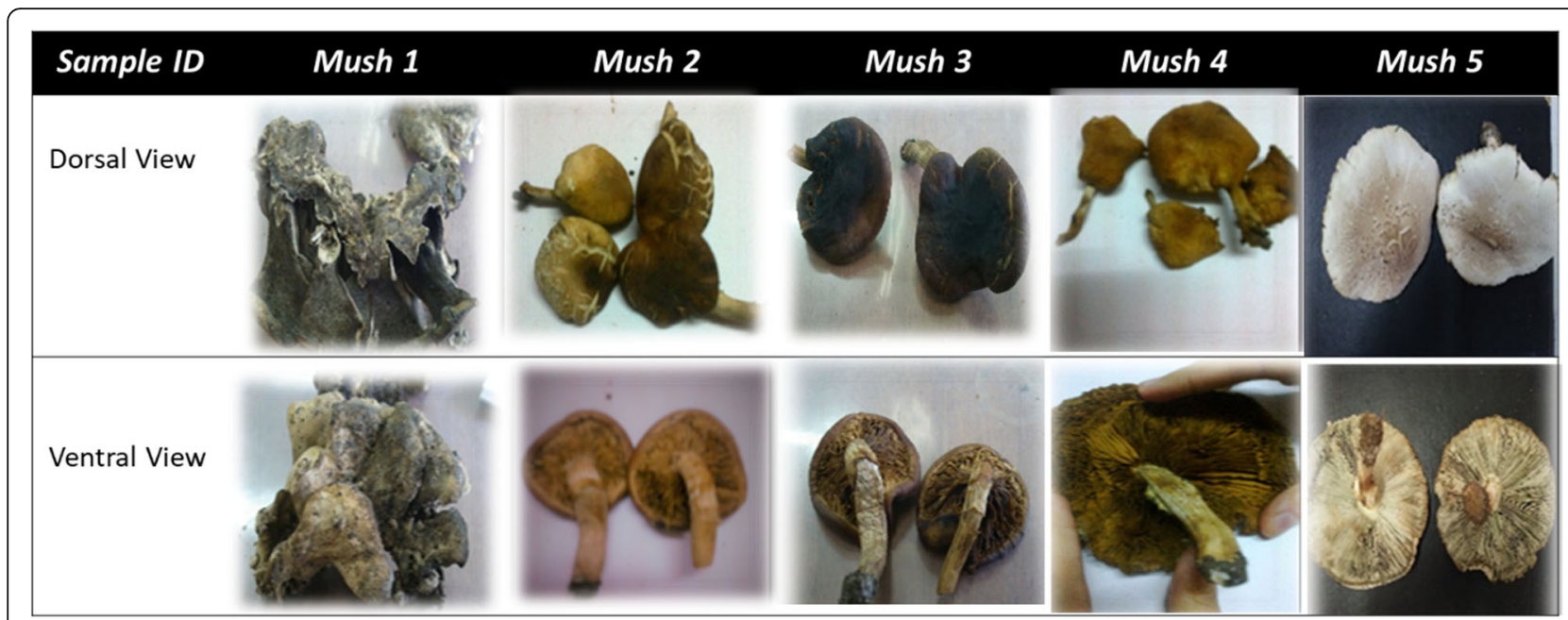

Fig. 1 Morphological characterization of the collected wild mushroom fruiting bodies

at $30{ }^{\circ} \mathrm{C}$ at constant shaking of $150 \mathrm{rpm}$ for $24 \mathrm{~h}$. The extracts were centrifuged at $3000 \mathrm{rpm}, 4{ }^{\circ} \mathrm{C}$ for $15 \mathrm{~min}$ to give a clear supernatant that was filtered through Whatman filter paper number 4 . The clear filtrate was concentrated by evaporation under vacuum, then the crude extract was stored at $4{ }^{\circ} \mathrm{C}$ for further use [21]. The crude extracts have been evaluated for their antimicrobial activity.

\section{Test microorganisms and growth conditions}

The antimicrobial activity of extracts from the investigated mushrooms was tested against 6 different pathogenic bacterial strains and one yeast species, namely, Candida albicans ATCC1031. Escherichia coli ATCC25922, Pseudomonas aeruginosa ATCC 7853, and Staphylococcus aureus ATCC25923 were kindly provided from Pharmaceutical Control Authority, Giza, Egypt, while Proteus mirabilis, Micrococcus luteus, and Streptococcus pneumoniae were in-house isolates. The strains were routinely cultured in Nutrient agar (Diffco) medium at $37{ }^{\circ} \mathrm{C}$. A single colony from each corresponding organism was inoculated into Nutrient broth medium and allowed to grow for $24 \mathrm{~h}$ at $37{ }^{\circ} \mathrm{C}$. The grown cultures were used for the antimicrobial assay.

In vitro antimicrobial activity assay of mushroom' extracts Antimicrobial assay of mushroom extracts was verified using the well diffusion method [22]. The inoculum size of each test organism was adjusted to a concentration of $1.5 \times 10^{8} \mathrm{CFU} / \mathrm{mL}$ by comparing with 0.5 McFarland standards. Bacteria and yeast seeded plates were prepared by inoculating $100 \mu \mathrm{l}$ suspension of each tested culture into nutrient agar media. Wells were made on the agar surface with a 6-mm cork borer. The extracts were dissolved in sterile distilled water to a final concentration of $10 \mu \mathrm{g} / \mathrm{ml}$. A hundred microliters of extracts were poured independently into the well using a sterile syringe. The seeded plates were refrigerated for $8 \mathrm{~h}$ at 4 ${ }^{\circ} \mathrm{C}$ to allow extract diffusion into agar then, were incubated at $37 \pm 2{ }^{\circ} \mathrm{C}$ for $24 \mathrm{~h}$. The plates were observed for the inhibition zone formation around the wells.

The inhibition zone was calculated by measuring the diameter of the inhibition zone around the well (in millimeters) including the well diameter in three independent replicas. The measurements were taken in three different fixed directions for each plate and the average values for the three independent replicas were tabulated. Gentamycin $(10 \mu \mathrm{g} /$ disk $)$ was used as a standard reference antibiotic.

\section{Chemical composition of the crude extract of Cyclocybe cylindracea and Agrocybe aegerita fruiting bodies}

Even identified differentially, Mush 2 and 3 show 100\% similarity based on the sequenced ITS-rDNA fragment that argues for the same species for both samples; however, dissimilar antimicrobial activities were detected. Therefore, both samples were used to evaluate their chemical compositions by measuring the total soluble sugars, proteins, and phenolic contents.

\section{Total soluble sugars}

As described by Umbreit et al., total sugars were estimated using the anthrone technique [23]. Six milliliters anthrone solution ( $2 \mathrm{~g}$ anthrone $/ \mathrm{L} \mathrm{H}_{2} \mathrm{SO}_{4}$ of $95 \%$ ) was added to $3 \mathrm{ml}$ mushroom extract and the mixture was kept in a boiling water bath for $3 \mathrm{~min}$. The formed color was measured at $620 \mathrm{~nm}$ by a spectrophotometer after cooling. The calibration curve was constructed with 
different concentrations of glucose as a standard. Total soluble sugar content of the sample was determined as glucose equivalent and expressed as milligrams per gram of the extract.

\section{Total soluble proteins}

Total soluble proteins were determined according to Lowry et al., [24]. One milliliter of each mushroom extract was mixed with $5 \mathrm{ml}$ of freshly prepared solution of $2 \%$ sodium carbonate, $4 \%$ sodium hydroxide, and $0.5 \%$ copper sulfate in $1 \%$ sodium tartrate. The mixture was incubated at room temperature for $10 \mathrm{~min}$ before the addition of $0.5 \mathrm{ml}$ Folin and made up to $10 \mathrm{ml}$. After $30 \mathrm{~min}$, the optical density of the mixture was measured at $750 \mathrm{~nm}$. The calibration curve was constructed with different concentrations of albumin bovine serum as a standard. The total soluble proteins were calculated using albumin bovine serum equivalent and expressed as milligrams per gram of the extract.

\section{Total phenolic contents}

Using Folin-Ciocalteu reagent and gallic acid as a standard, total phenolic contents were determined according to Kujala et al., (2000) [25]. Half a millimeter of each mushroom's extract was mixed well with $2.5 \mathrm{~mL}$ of 1:10 ethanol diluted Folin-Ciocalteu's reagent, $2 \mathrm{~mL}$ of $7.5 \%$ $\mathrm{Na}_{2} \mathrm{CO}_{3}$. After $15 \mathrm{~min}$ incubation at room temperature, the absorbance of mixtures was recorded by spectrophotometer at $765 \mathrm{~nm}$. Different concentrations of gallic acid as standard have been prepared to construct the calibration curve. The total phenolic contents were calculated as gallic acid equivalent (GAE) and expressed as milligram per gram of the extract (mg GAE/g sample extract).

\section{HPLC analysis}

According to Roberts et al., (2018) [26] HPLC was carried out at the National Research center, Cairo, Egypt using Agilent 1260 series with a C18 column (4.6 mm $\times$ $250 \mathrm{~mm}$ i.d., $5 \mu \mathrm{m}$ ) at $35{ }^{\circ} \mathrm{C}$ to identify and quantify the phenolics and related compounds present in Bjerkandera adusta extract as it displayed the highest antimicrobial activity [26]. The mobile phase consisted of water (A) and acetonitrile (B) at a flow rate of $1 \mathrm{ml} / \mathrm{min}$. The multi-wavelength detector was monitored at $280 \mathrm{~nm}$. The sample injection volume was $10 \mu \mathrm{l}$. For the quantitative analysis of phenolic compounds, a calibration curve was obtained by injection of different concentration of gallic acid, chlorogenic acid, catechin, caffeine, syringic acid, rutin, ellagic acid, coumaric acid, vanillin, ferulic acid, naringenin, propyl gallate, 4',7-dihydroxyisoflavone, quercetin, and cinnamic acid standards.

\section{Statistical analysis}

All analyses were performed in triplicate. The data were recorded as means \pm SD (standard deviation). The statistical (SPSS version 17.0) package program was used to perform one way ANOVA. $\mathrm{P} \leq 0.05$ is considered statistically significant.

\section{Results}

\section{Molecular identification of mushroom samples}

The amplified fragments of the ITS-rRNA encoding gene were varied in length among the collected samples. A similar fragment length of about $\sim 900 \mathrm{bp}$ was amplified from Mush 2, 3, and 4 while a fragment length of 700 bp was amplified from Mush 1 and a fragment length of $\sim 800$,bp was amplified from Mush 5 (Fig. 2).

The nucleotide sequences were aligned against the whole nucleotide collection database using the Basic Local Alignment Search Tool (BLAST) search program of the National Center for Biotechnology Information (NCBI) site. All the sequences were deposited into the NCBI database and the acquired accession numbers are listed in Table 1 with the BLAST results.

Based on percent of identity, mushrooms may be identified as follows: Mush 1 shows $99.8 \%$ identity to Bjerkandera adusta (accession KX426963). Both Mush 2 and 3 show 88.8 and $89.2 \%$ identity to both Cyclocybe cylindracea voucher TO AV97345a (accession KM260145)

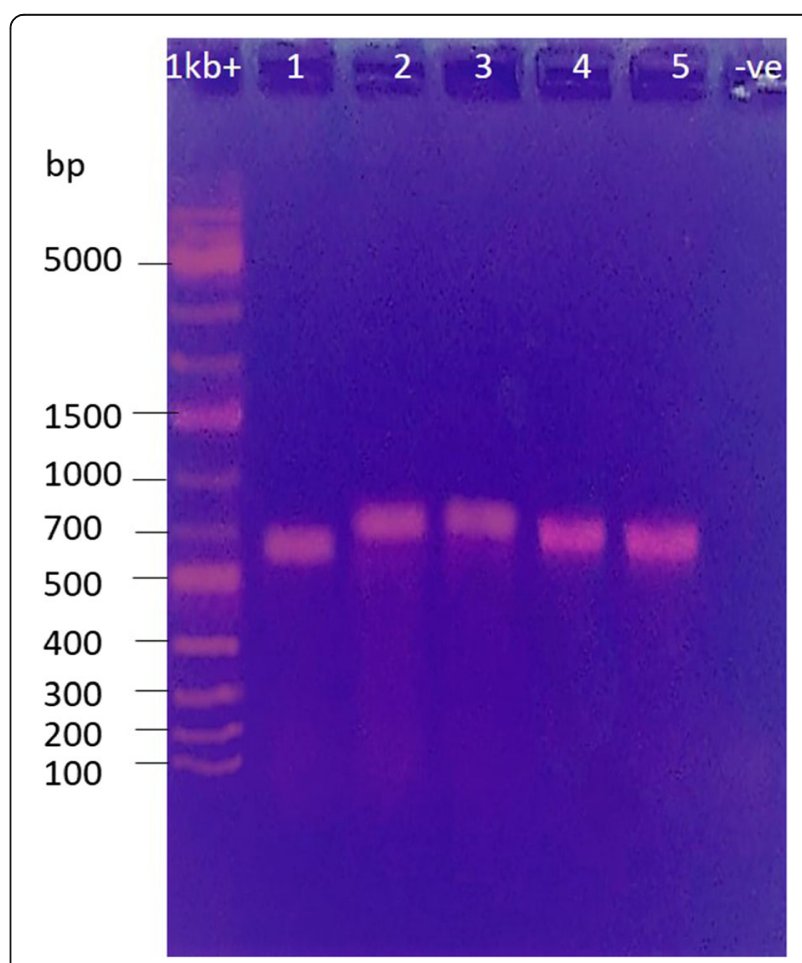

Fig. 2 PCR products amplified from five mushroom samples; lanes 1 to $5,1 \mathrm{~Kb}^{+}$refers to the DNA ladder; -ve refers to negative control of the PCR; no band indicates no PCR contamination 
Table 1 Summary of the NCBI nucleotide BLAST results and the deposited sequences' accession IDs

\begin{tabular}{llll}
\hline Samples ID & Sequence coverage \%/identity \% & Identified organism (ID) & Accession ID for the deposited sequences \\
\hline Mush $\mathbf{1}$ & $100 / 99.8$ & Bjerkandera adusta (KX426963) & MN602043 \\
Mush $\mathbf{2}$ & $95 / 88.8$ & Cyclocybe cylindracea (KM260145) & MN646676 \\
Mush $\mathbf{3}$ & $97 / 89.2$ & Agrocybe aegerita (AY763674) & MN635615 \\
Mush $\mathbf{4}$ & $81 / 93.4$ & Chlorophyllum molybdites (MG270072) & MN638772 \\
Mush $\mathbf{5}$ & $100 / 96.7$ & Lentinus squarrosulus (KF150321) & MN602044 \\
\hline
\end{tabular}

and Agrocybe aegerita strain SM970201 (accession AY763674), respectively. Mush 4 shows 93.3\% identity to Chlorophyllum molybdites strain LS091 (accession MG270072). Mush 5 shows $96.7 \%$ identity to Lentinus squarrosulus (accession KF150321).

All ITS sequences were aligned to each other to determine the pairwise similarities between sequences using quantity one software. The results show a maximum similarity of $100 \%$ was detected between Cyclocybe cylindracea and Agrocybe aegerita while the lowest similarity was detected between Chlorophyllum molybdites and all other mushrooms, Table 2 and Fig. 3.

The phylogenetic tree constructed revealed three major clades. The first clade includes the closely related species, Bjerkandera adusta and Lentinus squarrosulus. The second clade includes Cyclocybe cylindracea and Agrocybe aegerita with identical phylogenetic relationships. On the other hand, Chlorophyllum molybdites showed a distant relationship with other samples and was separated in the third clade, Fig. 4.

\section{In vitro antimicrobial activity}

Six pathogenic Gram-positive and Gram-negative bacteria and one yeast were screened against ethanol extracts from the studied mushroom strains to verify their antimicrobial activities. Except for Proteus mirabilis, the ethanolic extracts of Bjerkandera adusta and Cyclocybe cylindracea had the most effective antimicrobial activity against all the microorganisms examined. The largest inhibition zone of $22.0 \pm 0.10 \mathrm{~mm}$ was detected for Bjerkandera adusta extract against Micrococcus luteus while its lowest inhibition zone $(10.0 \pm 0.52 \mathrm{~mm})$ was detected against Pseudomonas aeruginosa ATCC7853. Agrocybe aegerita showed only very weak antimicrobial activity against Pseudomonas aeruginosa ATCC 7853 and Escherichia coli ATCC25922 of $2 \mathrm{~mm}$ inhibition zone. Ethanolic extracts of Chlorophyllum molybdites and Lentinus squarrosulus demonstrated strong antimicrobial activity against Streptococcus pneumoniae, Pseudomonas aeruginosa ATCC 7853, and no activity against the other strains. Gram-positive bacteria were more sensitive to the ethanolic extracts of Bjerkandera adusta and Cyclocybe cylindracea than Gram-negative bacteria (Table 3 and Fig. 5).

\section{Chemical composition of the crude extract of Cyclocybe cylindracea and Agrocybe aegerita fruiting bodies} Cyclocybe cylindracea and Agrocybe aegerita extracts were chemically analyzed for their different antimicrobial activity while they show $100 \%$ pairwise similarity for the ITS amplified fragment. The total phenols, sugars, and soluble protein content were varied between both samples. Interestingly, the highest contents were observed for Cyclocybe cylindracea. The data were represented in Fig. 6.

\section{HPLC analysis of Bjerkandera adusta ethanolic extract}

The highest antimicrobial activity was observed for Bjerkandera adusta ethanolic extract. Therefore, we aimed to identify its chemical constituents using HPLC. Many phenolics and related compounds (gallic acid, chlorogenic acid, catechin, caffeine, coffeic acid, syringic acid, rutin, propyl gallate, 4',7-dihydroxyisoflavone, quercetin, and cinnamic acid) were positively identified and quantified in the Bjerkandera adusta ethanolic extract as compared with the chromatographic characteristics and absorption spectra of standard compounds. Chlorogenic

Table 2 Percentage of pairwise similarity between five mushrooms; Bjerkandera adusta, Cyclocybe cylindracea, Agrocybe aegerita, Chlorophyllum molybdites, and Lentinus squarrosulus based on ITS sequencing data

\begin{tabular}{|c|c|c|c|c|c|}
\hline & Bjerkandera (Mush 1) & Cyclocybe (Mush 2) & Agrocybe (Mush 3) & Chlorophyllum (Mush 4) & Lentinus (Mush 5) \\
\hline \multicolumn{6}{|l|}{ Bjerkandera (Mush 1) } \\
\hline Cyclocybe (Mush 2) & 58.89 & & & & \\
\hline Agrocybe (Mush 3) & 59.21 & 100 & & & \\
\hline Chlorophyllum (Mush 4) & 42.65 & 35.44 & 35.64 & & \\
\hline Lentinus (Mush 5) & 82.06 & 58.03 & 58.03 & 45.45 & \\
\hline
\end{tabular}




Consensus
Agrocybe aegerita (Mush 3)
Cyclocybe cylindracea (Mush 2)
Chjerkandera adusta (Mush 1)
Fig. 3 Nucleotide alignmens squarrosulus (Mush 5)
Agrocybe aegerita, Chlorophyllum molybdites, and Lentinus squarrosulus based on ITS sequencing data

acid was the highest concentration of $11.33 \mu \mathrm{g} / \mathrm{ml}$ while only $0.47 \mu \mathrm{g} / \mathrm{ml}$ of gallic acid was the least, see Table 4 .

\section{Discussion}

With the growing demand for edible and medicinal mushrooms, research into the rich biodiversity of fungi is significant. Not only is it important to classify such highquality fungal species, but it has significant economic importance, as it can help to detect new bioactive products. Agaricomycetes serve as degrading organisms, pathogens, parasites, and ectomycorrhizal symbionts of forest trees. Mushroom identification using the ITS region has been proven to be efficient in taxonomic identification. ITSbased identification is specific and rapid, requires only a small amount of sample, and can apply for dried samples [12]. However, this approach does not directly reflect the dietary supplement contents or pharmacological activity of the specimen being studied [27]. In the present study, the ITS region of the rRNA encoding gene was successfully used to identify five wild mushrooms collected from two localities in Egypt: Al-Beheira Governorate and Cairo. Homology between sequences identified from samples was used to construct the phylogenetic relationship among the characterized species. The ITS region

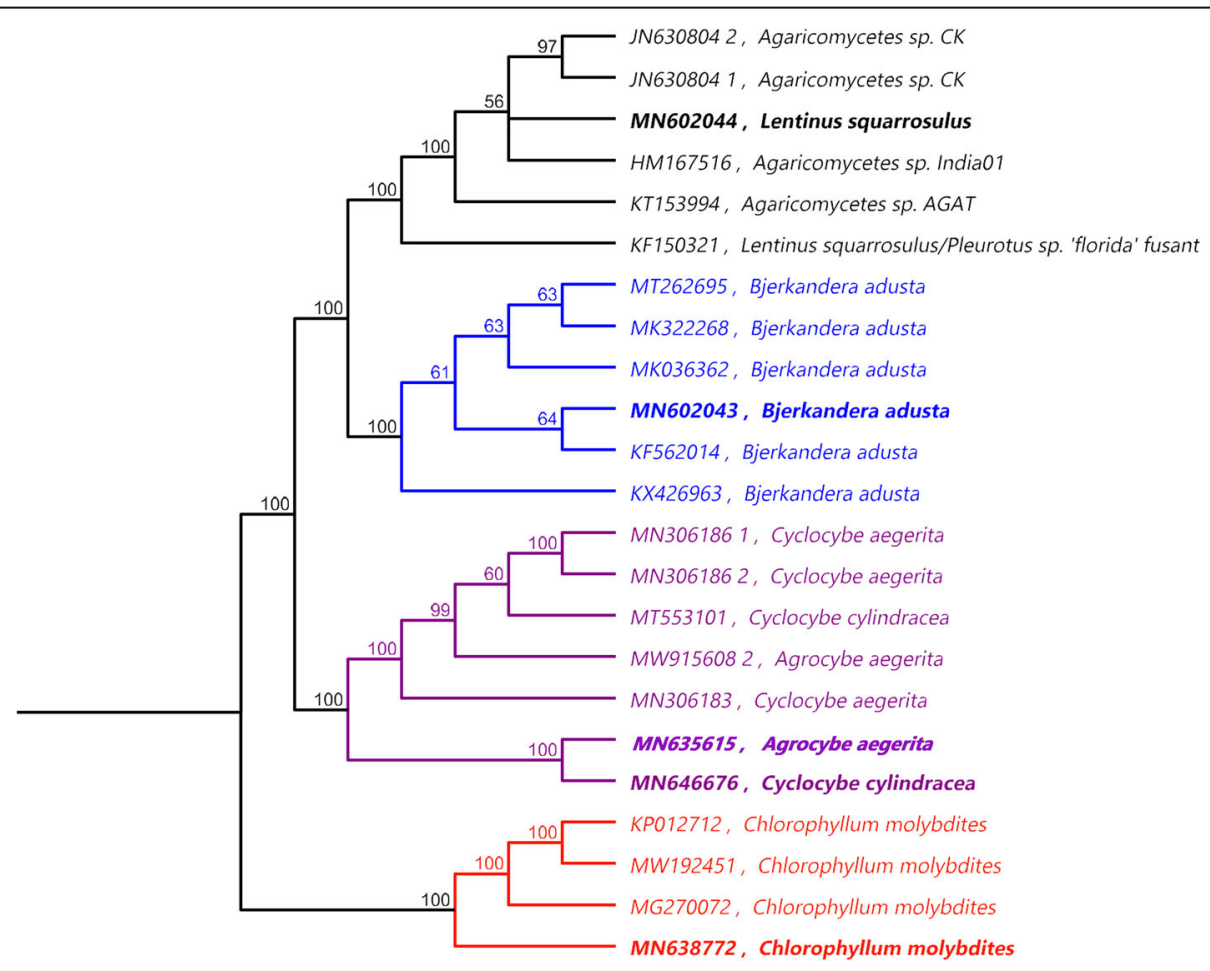

Fig. 4 phylogenetic tree generated using UPGMA tree build method based on ITS sequencing data of the different five mushroom samples (bold font) in relation to the most closest accessions in the database. The numbers on the nodes indicating the percent of 100 bootstrapping 
Table 3 Antimicrobial activities for the ethanolic extracts of different wild mushroom strains by using a well diffusion method

\begin{tabular}{|c|c|c|c|c|c|c|c|}
\hline \multicolumn{2}{|c|}{ Pathogenic microbial strains } & \multicolumn{6}{|c|}{ The diameter of inhibition zone $(\mathrm{mm})^{*}$} \\
\hline & & $\begin{array}{l}\text { Gentamycin } \\
(10 \mu \mathrm{g} / \text { well })\end{array}$ & $\begin{array}{l}\text { Bjerkandera } \\
\text { adusta } \\
\text { (MN602043) }\end{array}$ & $\begin{array}{l}\text { Cyclocybe } \\
\text { cylindracea } \\
\text { (MN646676) }\end{array}$ & $\begin{array}{l}\text { Agrocybe } \\
\text { aegerita } \\
\text { (MN635615) }\end{array}$ & $\begin{array}{l}\text { Chlorophyllum } \\
\text { molybdites } \\
\text { (MN638772) }\end{array}$ & $\begin{array}{l}\text { Lentinus } \\
\text { squarrosulus } \\
\text { (MN602044) }\end{array}$ \\
\hline \multirow{3}{*}{$\begin{array}{l}\text { Gram- } \\
\text { positive } \\
\text { bacteria }\end{array}$} & $\begin{array}{l}\text { Streptococcus } \\
\text { pneumoniae }\end{array}$ & $10.0 \pm 0.00$ & $17.0 \pm 0.20$ & $20.0 \pm 0.29$ & - & $12.0 \pm 0.33$ & $15.0 \pm 0.10$ \\
\hline & $\begin{array}{l}\text { Staphylococcus } \\
\text { aureus ATCC } 25923\end{array}$ & $8.0 \pm 0.00$ & $15.0 \pm 0.10$ & $13.0 \pm 0.12$ & - & - & - \\
\hline & Micrococcus luteus & $9.0 \pm 0.00$ & $22.0 \pm 0.10$ & $14.0 \pm 0.22$ & - & - & - \\
\hline \multirow{3}{*}{$\begin{array}{l}\text { Gram- } \\
\text { negative } \\
\text { bacteria }\end{array}$} & $\begin{array}{l}\text { Escherichia coli } \\
\text { ATCC25922 }\end{array}$ & $2.0 \pm 0.00$ & $12.0 \pm 0.30$ & $17.0 \pm 0.20$ & $2.0 \pm 0.00$ & - & - \\
\hline & $\begin{array}{l}\text { Pseudomonas } \\
\text { aeruginosa ATCC } \\
7853\end{array}$ & $10.0 \pm 0.00$ & $10.0 \pm 0.52$ & $17.0 \pm 0.00$ & $2.0 \pm 0.00$ & $10.0 \pm 0.41$ & $20.0 \pm 0.22$ \\
\hline & Proteus mirabilis & - & - & - & - & - & - \\
\hline Yeast & $\begin{array}{l}\text { Candida albicans } \\
\text { ATCC1031 }\end{array}$ & - & $12.0 \pm 011$ & $14.0 \pm 0.00$ & - & - & - \\
\hline
\end{tabular}

Values for the zone of growth inhibition (measured as the diameter of the clear zone around the well) are means \pm SD of three independent replicas. The diameter of the well $(5 \mathrm{~mm})$ is included

"_" indicates no inhibition

sequences of the Mush 1 matched the BLAST reference sample for Bjerkandera adusta. Interestingly, both Mush 2 and 3 show high sequences similarities to both Cyclocybe cylindracea and Agrocybe aegerita, respectively. Furthermore, the ITS nucleotide similarity and phylogenetic tree show that the Cyclocybe cylindracea is genetically identical to Agrocybe aegerita. The only acceptable explanation for the current observation is that both samples are representing one species. Based on DNA sequence analysis, Vizzini et al., (2014) [28] stated that Cyclocybe cylindracea is the synonymous new name to Agrocybe aegerita [28]. Nevertheless, both samples displayed differential antimicrobial activities that could be associated with different isolates as ecological habitats greatly influence chemical composition and physiological pathways for better fitness with the surrounding environment. Otherwise, it may be attributed to different stages of development and different chemical composition found in extracts [11]. In agreement, total phenolics, sugars, and proteins were higher in Cyclocybe cylindracea in comparison to Agrocybe aegerita (Fig. 6). Until recently, Niveiro and his coauthor were described the Cyclocybe cylindracea and Agrocybe aegerita as two independent genera which could explain the varied antimicrobial activities and the varied chemical composition of both samples [29].

ITS region sequences of Mush 4 matched the Chlorophyllum molybdites while Mush 5 shows homology to Lentinus squarrosulus. For all characterized samples, the

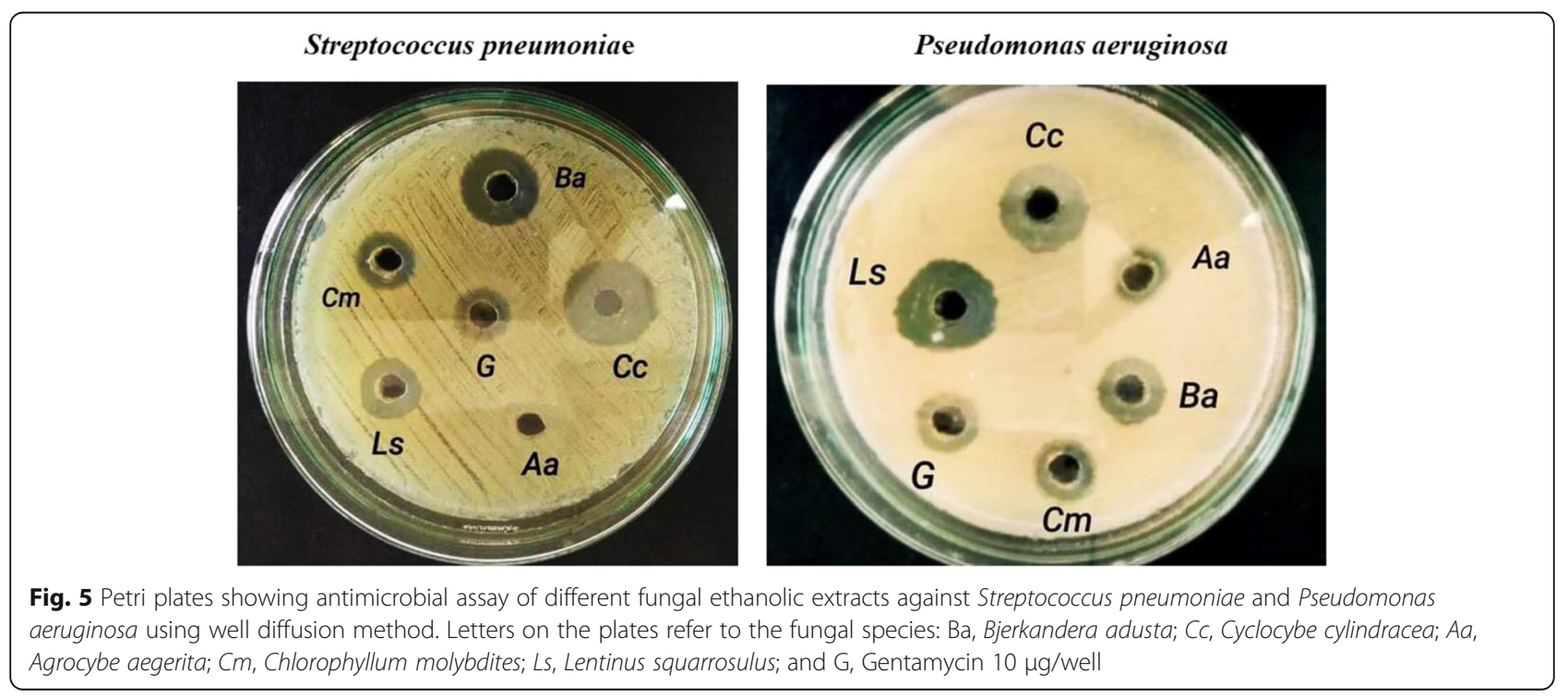




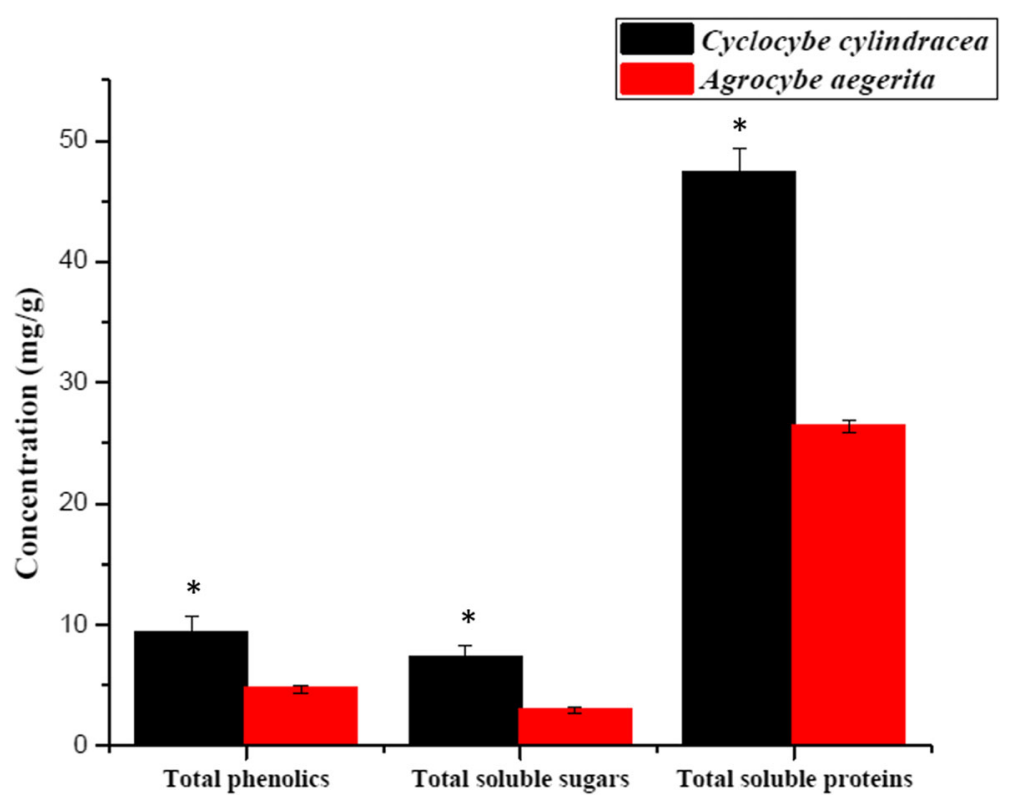

Fig. 6 Chemical composition of the crude extract of Cyclocybe cylindracea and Agrocybe aegerita fruiting bodies. Asterisk refers to significance at $p$ $<0.05$

morphological features were consistent with the molecular data up to species levels. The majority of the edible mushrooms are Agaricomycetes and being collected from the garden [30]. In agreement, the ITS-based identification of mushrooms collected for the present study shows that all belong to Agaricomycetes [31]. In the current study, most of the ITS sequences of different mushrooms native to Egypt are not 100\% homology with the reference gene sequence in NCBI GenBank, which may reflect the impact of the ecological habitat where the mushrooms are grown [30].

Our result validates how conserved sequences of mushrooms are primarily principle for their molecular identification and extended to understand their evolutionary basis. Detailed phylogenetic analyses showed that all mushroom samples fall into three major clades; Cyclocybe cylindracea and Agrocybe aegerita were genetically identical and separated together in one clade while Lentinus squarrosulus show $\sim 82 \%$ pairwise similarity to Bjerkandera adusta and so both of them are represented in the second clade. Chlorophyllum molybdites show the least pairwise similarity to all other mushrooms in which it reached a maximum of $\sim 42 \%$ with Bjerkandera adusta and a minimum of $\sim 35 \%$ with both Cyclocybe cylindracea and Agrocybe aegerita. Therefore, it was phylogenetically distinct from all others and was separated in the third clade. In accordance with Binder et al., (2005) [32] Bjerkandera adusta and Lentinus squarrosulus was

Table 4 Bioactive phenolic compounds detected in the Bjerkandera adusta ethanolic extract using HPLC analysis

\begin{tabular}{|c|c|c|c|c|c|c|}
\hline Compound name & Formula & Retention time (min) & Molecular mass $\left(\mathrm{g} \mathrm{mol}^{-1}\right)$ & Peak area & Area \% & Conc. $(\mu \mathrm{g} / \mathrm{ml})$ \\
\hline Gallic acid & $\mathrm{C}_{7} \mathrm{H}_{6} \mathrm{O}_{5}$ & 3.07 & 170.12 & 9.17 & 0.17 & 0.47 \\
\hline Chlorogenic acid & $\mathrm{C}_{16} \mathrm{H}_{18} \mathrm{O}_{9}$ & 3.45 & 354.31 & 204.81 & 3.74 & 11.33 \\
\hline Catechin & $\mathrm{C}_{15} \mathrm{H}_{14} \mathrm{O}_{6}$ & 3.83 & 290.26 & 25.88 & 0.47 & 5.88 \\
\hline Caffeine & $\mathrm{C}_{8} \mathrm{H}_{10} \mathrm{~N}_{4} \mathrm{O}_{2}$ & 4.06 & 194.19 & 84.02 & 1.54 & 2.10 \\
\hline Coffeic acid & $\mathrm{C}_{9} \mathrm{H}_{8} \mathrm{O}_{4}$ & 4.82 & 180.16 & 62.04 & 1.13 & 1.63 \\
\hline Syringic acid & $\mathrm{C}_{9} \mathrm{H}_{10} \mathrm{O}_{5}$ & 5.15 & 198.17 & 38.75 & 0.71 & 1.24 \\
\hline Rutin & $\mathrm{C}_{27} \mathrm{H}_{30} \mathrm{O}_{16}$ & 5.55 & 610.517 & 34.17 & 0.62 & 3.93 \\
\hline Propyl gallate & $\mathrm{C}_{10} \mathrm{H}_{12} \mathrm{O}_{5}$ & 10.29 & 212.2 & 88.14 & 1.61 & 2.74 \\
\hline 4'7-dihydroxyisoflavone & $\mathrm{C}_{15} \mathrm{H}_{10} \mathrm{O}_{4}$ & 10.44 & 254.241 & 101.21 & 1.85 & 1.86 \\
\hline Quercetin & $\mathrm{C}_{15} \mathrm{H}_{10} \mathrm{O}_{7}$ & 10.57 & 302.236 & 79.52 & 1.45 & 4.46 \\
\hline Cinnamic acid & $\mathrm{C}_{9} \mathrm{H}_{8} \mathrm{O}_{2}$ & 11.16 & $\mathrm{C} 9 \mathrm{H} 8 \mathrm{O} 2$ & 855.07 & 15.62 & 5.37 \\
\hline
\end{tabular}


phylogenetically close and grouped in a polyporoid clade while Chlorophyllum molybdites was phylogenetically distinct and distributed in the euagaricus clade [32].

The molecular taxonomy of wild mushrooms would enable researchers and people interested in the mushroom industry to detect the current widespread existing species and the endangered species to protect [12]. This direction would be applicable if the molecular identification of mushrooms is coupled with the identification of their antimicrobial activities or their chemical constituents to evaluate their economic importance whether as a source of food or as pharmaceutical products.

Recently, new effective metabolites against pathogenic microorganisms resistant to traditional treatments should be established. Here, as an alternative, wild mushrooms were evaluated. In pursuit of new antimicrobial agents, mushrooms were screened for antimicrobial activity [33]. Different types of mushrooms were found to display different antimicrobial behaviors. In the present study, ethanolic extracts from five wild mushrooms have been evaluated for antimicrobial activity against various pathogens. Screening of the antimicrobial activity against Gram-positive, Gram-negative bacteria, and the yeast of the ethanolic wild mushroom extracts showed that Agrocybe aegerita, Chlorophyllum molybdites, and Lentinus squarrosulus had little activity against pathogenic bacteria and yeast examined. Alternatively, except for Proteus mirabilis, Bjerkandera adusta and Cyclocybe cylindracea extracts exhibit relatively strong antimicrobial activity against all bacteria and yeast tested. For extracts, the inhibition region exhibiting more than $10 \mathrm{~mm}$ was considered highly active. Barneche et al., (2016) [34] reported that Bjerkandera adusta exhibited antimicrobial activity against Xanthomonas vesicatoria, Aspergillus oryzae, Penicillium expansum, Botrytis cinerea, and Rhizopus stolonifera [34]. In contrast to the current result, Chikwem et al., (2020) observed that B. adusta aqueous, methanol, and ethanol extracts demonstrated no antimicrobial activity against Candida albicans. However, some B. adusta extracts were highly effective against three Gram-negative bacteria (Escherichia coli, Salmonella typhimurium, and Pseudomonas aeruginosa) and three Gram-positive bacteria (Staphylococcus aureus, Staphylococcus epidermidis, and Bacillus cereus) [35]. In agreement with Kumar et al., (2016) [36] Cyclocybe cylindracea displayed a strong antimicrobial activity against Gram-positive Staphylococcus aureus and Gram-negative Klebsiella pneumonia and E. coli that was attributed to its polysaccharide content [36]. Overall, the strength of the antimicrobial activity depends on the mushroom species, chemical composition, and the microbe being tested.

Phytochemicals, especially phenolic compounds and flavonoids, have been considered as a valuable source of relatively cheap and safe antimicrobial agents with very few adverse effects [37]. There have been limited investigations concerning the individual profiles of phenolic compounds in wild mushrooms. The phenolic content of the ethanol extract of the most potent species, Bjerkandera adusta, was investigated in our study. HPLC analysis revealed 11 different phenolic compounds with various concentrations. Previous studies have confirmed the presence of various derivatives of benzoic acid, cinnamic acid, and its derivatives, and some flavonoids in various mushroom species $[15,38]$. Chlorogenic acid was the highest phenolic detected of $11.33 \mu \mathrm{g} / \mathrm{ml}$, the presence of it may explain the strong antimicrobial activity of Bjerkandera adusta as it bounds the pathogen's outer membrane disrupting its permeability, defect barrier activity, causing minor leakage of nucleotide and cytoplasmic material consequently cell death [39]. Catechin was also detected to $5.88 \mu \mathrm{g} / \mathrm{ml}$. Catechin produces hydrogen peroxide that damages bacterial cell membranes [40]. Gallic acid of $0.47 \mu \mathrm{g} / \mathrm{ml}$ was quantified in our sample in which the antimicrobial activity could be attributed to it. Gallic acid exhibits antimicrobial action against different bacteria, such as Pseudomonas strains [41]. Additionally, it improves antimicrobials efficiency possibly by inhibiting efflux pumps, which are important mechanism for producing antimicrobial resistance [42, 43]. $1.63 \mu \mathrm{g} / \mathrm{ml}$ of caffeic acid was quantified in Bjerkandera adusta extract, it associates with cell membrane integrity destruction and interferes with $S$. aureus cell aerobic metabolism [44]. Numerous studies have shown that flavonoid antibacterial mechanisms (quercetin-flavonol, 4',7-dihydroxyisoflavone, rutin) mainly include inhibition of nucleic acid synthesis, inhibition of cytoplasmic membrane function by affecting the formation of biofilms, porins, permeability, and interaction with certain critical enzymes [45, 46]. Overall, the observed strong antimicrobial activity of Bjerkandera adusta could be attributed to synergistic interactions between various natural phenolics and flavonoids detected in its extract.

The results from this research are of particular importance in terms of finding new, wild species of medicinal mushrooms that contain bioactive components. The antimicrobial potential proven in the analyzed mushroom extracts shows that they can be used in the food industry as a substitute for synthetic antimicrobial compounds. At the same time, the extract can be a basis for use in alternative medicine.

\section{Conclusion}

In conclusion, an accurate phylogenetic analysis establishes a theoretical method for defining a classified status of new edible or medicinal mushrooms. Besides, their evolutionary relationships could provide an important clue for further exploration of the active compounds. 
Furthermore, molecular characterization is the authentication of wild mushrooms. Drug-resistant microbial strains have been creating serious treatment problems. This situation has forced the search for new antimicrobial drugs effective against pathogenic microorganisms. Wild mushrooms, as a natural source, could be an alternative being included in the diet. The mechanism of antibacterial action of the best extracts (e.g., Bjerkandera adusta and Cyclocybe cylindracea) should be elucidated and the individual/combined compounds found in those extracts might be tested against selected bacteria to identify molecules responsible for the bioactivity.

\section{Abbreviations}

rDNA-ITS: Ribosomal DNA internal transcribed spacers regions;

Mush: Mushroom; HPLC: High-performance liquid chromatography;

NCBI: National Center for Biotechnology Information; BLAST: Basic Local

Alignment Search Tool

\section{Acknowledgements}

"Not applicable"

\section{Authors' contributions}

ERSS performs the molecular identification analysis, submit sequences to gene-bank and obtained the accessions numbers, perform the phylogenetic analysis, analyse the data, has written the manuscript, revised it, and corresponding the publication. HE collected the samples, performs the antimicrobial and biochemical assay and has written the manuscript. The authors read and approved the final manuscript.

\section{Funding}

This study received no funding grant

\section{Availability of data and materials}

All data generated or analyzed during this study are included in this article.

\section{Declarations}

Ethics approval and consent to participate

Not applicable

\section{Consent for publication}

Not applicable

\section{Competing interests}

The authors declare that they have no competing interests.

Received: 17 March 2021 Accepted: 16 June 2021

Published online: 19 July 2021

\section{References}

1. Das K (2010) Diversity and conservation of wild mushrooms in Sikkim with special reference to Barsey Rhododendron Sanctuary. NeBIO 1:1-13

2. Rashid S, Aminuzzaman F, Islam M, Rahaman M, Rumainul M (2016) Biodiversity and distribution of wild mushrooms in the Southern Region of Bangladesh. J Adv Biol Biotechnol 9(1):1-25. https://doi.org/10.9734/jabb/2 $016 / 27711$

3. Gebreyohannes G, Nyerere A, Bii C, Berhe SD (2019) Determination of antimicrobial activity of extracts of indigenous wild mushrooms against pathogenic organisms. Evid Based Compl Altern Med 2019:1-7. https://doi. org/10.1155/2019/6212673

4. González-Palma I, Escalona-Buendía HB, Ponce-Alquicira E, Téllez-Téllez M, Gupta VK, Díaz-Godínez G, Soriano-Santos J (2016) Evaluation of the antioxidant activity of aqueous and methanol extracts of Pleurotus ostreatus in different growth stages. Front Microbiol 7:1-9. https://doi.org/10.3389/ fmicb.2016.01099

5. Temesgen T (2018) Application of mushroom as food and medicine. Adv Biotechnol Microbiol 11(4). https://doi.org/10.19080/aibm.2018.11.555817
6. Sevindik M (2018) Investigation of antioxidant/oxidant status and antimicrobial activities of Lentinus tigrinus. Adv Pharmacol Sci 2018:1-4. https://doi.org/10.1155/2018/1718025

7. Duru ME, Cayan GT (2015) Biologically active terpenoids from mushroom origin: a review. Rec Nat Prod 9:456-483

8. Vamanu E, Pelinescu D, Avram I (2018) Antioxidative Effects of Phenolic Compounds of mushroom mycelia in simulated regions of the human colon, in vitro study. Polish J Food Nutr Sci 68(1):83-90. https://doi.org/10.1 515/pjfns-2017-0010

9. Golak-Siwulska I, Kałuzewicz A, Spizewski T, Siwulski M, Sobieralski K (2018) Bioactive compounds and medicinal properties of Oyster mushrooms (Pleurotus sp.). Folia Hortic 30(2):191-201. https://doi.org/10.2478/fhort-20180012

10. Yang R-H, Su J-H, Shang J-J, Wu Y-Y, Li Y, Bao D-P, Yao YJ (2018) Evaluation of the ribosomal DNA internal transcribed spacer (ITS), specifically ITS1 and ITS2, for the analysis of fungal diversity by deep sequencing. PLoS One 13(10):e0206428. https://doi.org/10.1371/journal.pone.0206428

11. Adeniyi M, Titilawo Y, Oluduro A, Odeyemi O, Nakin M, Okoh Al (2018) Molecular identification of some wild Nigerian mushrooms using internal transcribed spacer: polymerase chain reaction. AMB Express 8(1):148. https:// doi.org/10.1186/s13568-018-0661-9

12. Raja HA, Baker TR, Little JG, Oberlies NH (2017) DNA barcoding for identification of consumer-relevant mushrooms: a partial solution for product certification? Food Chem 214:383-392. https://doi.org/10.1016/j. foodchem.2016.07.052

13. Ozen T, Darcan C, Aktop OTI (2011) Screening of antioxidant, antimicrobial activities and chemical contents of edible mushrooms wildly grown in the black sea region of Turkey. Comb Chem High Throughput Screen 14(2):7284. https://doi.org/10.2174/138620711794474079

14. Lou Z, Wang H, Rao S, Sun J (2012) ma Chaoyang JL. p-Coumaric acid kills bacteria through dual damage mechanisms. Food Control 25(2):550-554. https://doi.org/10.1016/j.foodcont.2011.11.022

15. Alves MJ, Ferreira ICFR, Froufe HJC, Abreu RMV, Martins A, Pintado M (2013) Antimicrobial activity of phenolic compounds identified in wild mushrooms, SAR analysis and docking studies. J Appl Microbiol 115(2):346-357. https:// doi.org/10.1111/jam.12196

16. Kim M-Y, Seguin P, Ahn J-K, Kim J-J, Chun S-C, Kim E-H, Seo S-H, Kang E-Y, Kim S-L, Park Y-J, Ro H-M, Chung I-M (2008) Phenolic compound concentration and antioxidant activities of edible and medicinal mushrooms from Korea. J Agric Food Chem 56(16):7265-7270. https://doi. org/10.1021/jf8008553

17. Largent DL, Stuntz DE (1986) How to identify mushrooms to genus I: macroscopic features. Revised ed. Mad River Press

18. Das SK (2013) Morphological, biochemical and molecular characterization of some wild edible mushroom of Eastern Chotonagpur part of West Bengal. University of Kalyani, West Bengal, India

19. Vejlupkova Z, Fowler J (2003) Maize DNA preps for undergraduate students a robust method for PCR genotyping. MNL 77:24-25

20. Kearse M, Moir R, Wilson A, Stones-Havas S, Cheung M, Sturrock S, Buxton S, Cooper A, Markowitz S, Duran C, Thierer T, Ashton B, Meintjes P, Drummond A (2012) Geneious basic: an integrated and extendable desktop software platform for the organization and analysis of sequence data. Bioinformatics 28(12):1647-1649. https://doi.org/10.1 093/bioinformatics/bts199

21. Lin CH, Chang CY, Lee KR, Lin HJ, Lin WC, Chen TH, Wan L (2016) Coldwater extracts of Grifola frondosa and its purified active fraction inhibit hepatocellular carcinoma in vitro and in vivo. Exp Biol Med 241(13):13741385. https://doi.org/10.1177/1535370216640149

22. Balouiri M, Sadiki M, Ibnsouda SK (2016) Methods for in vitro evaluating antimicrobial activity: a review. J Pharm Anal 6(2):71-79. https://doi.org/10.1 016/j.jpha.2015.11.005

23. Umbreit WW, Burris R, Stauffer JF (1964) Monometric technique, a manual describing methods applicable to the study of tissue metabolism, 4th edn, Burgess, Minneapolis

24. Lowry O, Rosebrough N, Farr A, Randall R (1951) Protein measurement with the Folin phenol reagent. J Biol Chem 193(1):265-275. https://doi.org/10.101 6/S0021-9258(19)52451-6

25. Kujala TS, Loponen JM, Klika K, Pihlaja K (2000) Phenolics and betacyanins in red beetroot (Beta vulgaris) root: distribution and effect of cold storage on the content of total phenolics and three individual compounds. J Agric Food Chem 48:5338-5342. https://doi.org/10.1021/jf000523q 
26. Roberts CE, Raner GM, Isaacs GD (2018) High performance liquid chromatography separation of epigenetic cytosine variants. Methods Protoc 1(2):1-8. https://doi.org/10.3390/mps1020010

27. Barros L, Cruz T, Baptista P, Estevinho LM, Ferreira ICFR (2008) Wild and commercial mushrooms as source of nutrients and nutraceuticals. Food Chem Toxicol 46(8):2742-2747. https://doi.org/10.1016/j.fct.2008.04.030

28. Vizzini A, Angelini C, Ercole E (2014) Le sezioni Velatae e Aporus di Agrocybe sottogenere Aporus: rivalutazione del genere Cyclocybe Velen. ed una nuova specie. Boll Assoc Micol Ecol Rom 30:21-38

29. Niveiro N, Uhart M, Albertó E (2020) Revision of the genera Agrocybe and Cyclocybe (Strophariaceae, Agaricales, Basidiomycota) in Argentina. Rodriguésia 71:1-26. https://doi.org/10.1590/2175-7860202071038

30. Ndyetabura T, Lyantagaye SL, Mshandete AM (2010) Antimicrobial activity of ethyl acetate extracts from edible Tanzanian Coprinus cinereus (Schaeff ) S. Grays . lat . cultivated on grasses supplemented with cow dung manure. ARPN J Agric Biol Sci 5:79-85

31. Hibbett DS, Bauer R, Binder M, Giachini AJ, Hosaka K, Justo A, et al. Agaricomycetes. In: McLaughlin DJ SJ, editor. mycota, Syst. Evol. part A, vol. 6. 2nd edn., Berlin, Germany: Springer-Verlag, 373-429.; 2014, p. 57.

32. Binder M, Hibbett DS, Larsson K-H, Larsson E, Langer E, Langer G (2005) The phylogenetic distribution of resupinate forms across the major clades of mushroom-forming fungi (Homobasidiomycetes). Syst Biodivers 3(2):113157. https://doi.org/10.1017/S1477200005001623

33. Nikolovska-Nedelkoska D, Atanasova-Pancevska N, Amedi H, Veleska D, Ivanova E, Karadelev M, Kungulovski D (2013) Screening of antibacterial and antifungal activities of selected Macedonian wild mushrooms. Zb Matice Srp Za Prir Nauk Srp J Nat Sci (124):333-340. https://doi.org/10.2298/ zmspn1324333n

34. Barneche $\mathrm{S}$, Jorcin $\mathrm{G}$, Cecchetto $\mathrm{G}$, Cerdeiras $\mathrm{M}$, Vázquez A, Alborés $\mathrm{S}$ (2016) Screening for antimicrobial activity of wood rotting higher basidiomycetes mushrooms from Uruguay against phytopathogens. Int J Med Mushrooms 18(3):261-267. https://doi.org/10.1615/ IntJMedMushrooms.v18.13.90

35. Chikwem J, Jonathan GS, Group AM, Hull A (2020) Antimicrobial potential of Trichaptum biforme and Bjerkandera adusta from Pennsylvania, USA. J Nat Sci Res. https://doi.org/10.7176/insr/11-16-01

36. Kumar SS, Shankar S, Mohan SC (2016) In vitro antioxidant and antimicrobial activity of polysaccharides extracted from edible mushrooms Pleurotus florida and Agrocybe cylindracea. Singapore J Chem Biol 6(1):17-22. https:// doi.org/10.3923/sjchbio.2017.17.22

37. Nascimento GGF, Locatelli J, Freitas PC, Silva GL (2000) Antibacterial activity of plant extracts and phytochemicals on antibiotic-resistant bacteria. Braz Microbiol 31(4):247-256. https://doi.org/10.1590/S1517-83822000000400003

38. Stojanova M, Pantić M, Karadelev M, Čuleva B, Nikšić M (2020) Antioxidant potential of extracts of three mushroom species collected from the Republic of North Macedonia. J Food Process Preserv 45(2):1-10. https://doi. org/10.1111/jpp. 15155

39. Lou Z, Wang H, Zhu S, Ma C, Wang Z (2011) Antibacterial activity and mechanism of action of chlorogenic acid. J Food Sci 76(6):M398-M403. https://doi.org/10.1111/j.1750-3841.2011.02213.x

40. Arakawa H, Maeda M, Okubo S, Shimamura T (2004) Role of hydrogen peroxide in bactericidal action of catechin. Biol Pharm Bull 27(3):277-281. https://doi.org/10.1248/bpb.27.277

41. Samad MA, Hashim SH, Simarani K, Yaacob JS (2016) Antibacterial properties and effects of fruit chilling and extract storage on antioxidant activity, total phenolic and anthocyanin content of four date palm (Phoenix dactylifera) cultivars. Molecules 21(4):1-14. https:// doi.org/10.3390/molecules21040419

42. Simões M, Bennett RN, Rosa EAS (2009) Understanding antimicrobial activities of phytochemicals against multidrug resistant bacteria and biofilms. Nat Prod Rep 26(6):746-757. https://doi.org/10.1039/b821648g

43. Abreu AC, McBain AJ, Simões M (2012) Plants as sources of new antimicrobials and resistance-modifying agents. Nat Prod Rep 29(9):10071021. https://doi.org/10.1039/c2np20035j

44. Luís Â, Silva F, Sousa S, Duarte AP, Domingues F (2014) Antistaphylococcal and biofilm inhibitory activities of gallic, caffeic, and chlorogenic acids. Biofouling 30(1):69-79. https://doi.org/10.1080/08927014.2013.845878
45. Farhadi F, Khameneh B, Iranshahi M, Iranshahy M (2019) Antibacterial activity of flavonoids and their structure-activity relationship: an update review. Phyther Res 33(1):13-40. https://doi.org/10.1002/ptr.6208

46. Górniak I, Bartoszewski R, Króliczewski J (2019) Comprehensive review of antimicrobial activities of plant flavonoids. 18. https://doi.org/10.1007/s111 01-018-9591-z

\section{Publisher's Note}

Springer Nature remains neutral with regard to jurisdictional claims in published maps and institutional affiliations.

\section{Submit your manuscript to a SpringerOpen ${ }^{\circ}$ journal and benefit from:}

- Convenient online submission

- Rigorous peer review

- Open access: articles freely available online

High visibility within the field

- Retaining the copyright to your article

Submit your next manuscript at $\boldsymbol{\nabla}$ springeropen.com 